\title{
Nitrogen dioxide exposure and health risk assessments of students in elementary schools in the vicinities of an industrial estate, located in Rayong Province, Thailand
}

\author{
Suganya Phantu, Susira Bootdee ${ }^{\dagger}$ \\ Faculty of Science, Energy, and Environment, King Mongkut's University of Technology North Bangkok (Rayong Campus), Rayong, 21120, Thailand
}

\begin{abstract}
Exposure to nitrogen dioxide $\left(\mathrm{NO}_{2}\right)$ poses a danger to the health of many children all over the world especially children that attend schools in the vicinities of traffic roads and industries. This research study aims to assess the impacts of $\mathrm{NO}_{2}$ exposure on the health of the students. $\mathrm{NO}_{2}$ samples were collected by tube-type passive samplers. Moreover, the investigation of indoor $\mathrm{NO}_{2}$ exposure of students was associated with physical human health by using multiple logistic regressions. The results revealed that the indoor and outdoor $\mathrm{NO}_{2}$ concentrations in elementary schools were $9.0 \pm 4.4$ to $16.7 \pm 2.7 \mu \mathrm{g} / \mathrm{m}^{3}$ and $8.2 \pm 2.1$ to $17.7 \pm 6.7 \mu \mathrm{g} / \mathrm{m}^{3}$, respectively. However, indoor and outdoor values of $\mathrm{NO}_{2}$ were lower than the WHO standard of $40 \mu \mathrm{g} / \mathrm{m}^{3}$. Non-carcinogenic risk assessments of $\mathrm{NO}_{2}$ were carried out to help assess the health risks of students. It was found that the $\mathrm{HQ}$ of all those who studied in schools was less than 1 , indicating no health risks. However, $\mathrm{NO}_{2}$ in classrooms can cause eye irritation ( $p$-value $=0.007)$, pink eye/ allergic conjunctivitis ( $p$-value $=0.012)$, runny nose $(p$-value $=0.020)$, sore throat $(p$-value $=$ 0.038 ), wheeze ( $\mathrm{p}$-value $=0.022)$ and cough ( $\mathrm{p}$-value $=0.035)$. Therefore, children who spend time in classrooms close to heavy traffic and petrochemical plants might find themselves exposed to increased health risks.
\end{abstract}

Keywords: Environmental school, Hazard quotient, Health risk assessment, Indoor air pollution, Nitrogen dioxide

\section{Introduction}

Air pollution is one of the global problems that directly affect children's health around the world especially in industrialized areas. Children are at greater risk and have a longer life expectancy than adults from the many adverse health effects of air pollution. Children have latent disease mechanisms that emerge and affect especially their lungs as they become rapidly weak to inflammation and other damage caused by pollutants [1]. The WHO reported almost $10 \%$ of childhood acute lower respiratory infection (ALRI) deaths are associated with ambient and household air pollutions in 2016 [2]. The ambient and household air pollutions are linked with 52,000 deaths of children aged 5-15 years. Exposure to pollutants such as fine particulate matter $\left(\mathrm{PM}_{2.5}\right)$, nitrogen dioxide $\left(\mathrm{NO}_{2}\right)$, carbon oxide (CO), sulfur dioxide $\left(\mathrm{SO}_{2}\right)$, and ozone $\left(\mathrm{O}_{3}\right)$ were associated with different health problems in children [3]. For example, some authors have reported about $\mathrm{O}_{3}, \mathrm{NO}_{2}, \mathrm{PM}_{2.5}$, and coarse particulate matter $\left(\mathrm{PM}_{10}\right)$ were linked to the development of asthma,

This is an Open Access article distributed under the term of the Creative Commons Attribution Non-Commercial License (http://creativecommons.org/licenses/by-nc/3.0/) which permits unrestricted non-commercial use, distribution, and reproduction in any medium, provided the original work is properly cited.

Copyright (C) 2022 Korean Society of Environmental Engineers pneumonia, lung function, and other respiratory infections in children [4-7]. Children could be exposed to any of these pollutants from different places or routes which includes their homes, schools, through recreational facilities. Amongst all these places, the school environment is where students spend most of their hours of the day. Numerous studies point out that the main source of indoor pollutants is influenced by outdoor pollution such as traffic, industry, or combustion, while human activity inside includes painting, cleaning, building equipment, and furnishings [4, 8]. Several researchers have reported that indoor air pollution associated with $\mathrm{NO}_{2}$ can be found in schools $[5,9,10]$. The indoor $\mathrm{NO}_{2}$ found in schools are reported to have come from outdoor sources such as traffic and industrious industrial plants [9-11].

Nitrogen dioxide is a common gaseous pollutant released through vehicular emissions. It is the most toxic form of nitrogen oxide $\left(\mathrm{NO}_{\mathrm{x}}\right.$ ). Gokul Raj and Karthikeyan [12] revealed the mean of exposure $\mathrm{NO}_{2}$ concentrations for traveling by motorbike, car and bus were $1.04 \pm 0.4,0.69 \pm 0.3$ and $0.89 \pm 0.3 \mu \mathrm{g} / \mathrm{m}^{3} / \mathrm{min}$,

Received August 13, 2021 Accepted October 20, 2021

${ }^{\dagger}$ Corresponding author

E-mail: susira.b@sciee.kmutnb.ac.th

Tel: +6638 627000(5704)

ORCID: 0000-0003-4486-9544 
respectively. Previously studied sources of $\mathrm{NO}_{2}$ inside school classrooms can be associated with the influence of outdoor air pollution. Villanueva et al. [10] investigated the levels of indoor $\mathrm{NO}_{2}$ in schools located in urban, industrial, and rural areas in Central-Southern Spain. They revealed that the Principle Component Analysis (PCA) to identify a common source of $\mathrm{NO}_{2}$ was originated from an outdoor source in the industrial area. Findings from Ayuni and Juliana [5] indicated that exposure to indoor $\mathrm{NO}_{2}$ concentrations may increase health risk among primary school children living near the petrochemical industry. Moreover, Ielpo et al. [13] presented the distribution source of $\mathrm{NO}_{2}$ released mainly from the vehicular traffic and secondarily to industrial source. The petrochemical industry can be a significant source of $\mathrm{NO}_{\mathrm{x}}[14,15]$.

Passive samplers have been shown to be efficient, cost-effective, and do not require extensive calibration or maintenance. It can be attached to any object or person, depending on the measurement's goal. After sampling, the passive sampler remains stable for several months and can be easily carried before and after exposure. As a result, it was ideal for developing a wide spatial network for $\mathrm{NO}_{2}$ monitoring. In several countries, passive samplers have been used to monitor $\mathrm{NO}_{2}$ concentrations in the outdoor and indoor air. In Italy, Motta et al. [16] developed passive sampler for evaluating $\mathrm{NO}_{\mathrm{x}}\left(\mathrm{NO}+\mathrm{NO}_{2}\right)$ and reduced the hazards associated with the exposure to contaminants that are harmful to health. Using passive samplers, researchers in Thailand found that ambient $\mathrm{NO}_{2}$ concentrations at schools in Tha sala district, Nakhon Si Thammarat province by using passive samplers were greater at semester start (48.6 \pm 2.3 to $\left.78.1 \pm 11.5 \mu \mathrm{g} / \mathrm{m}^{3}\right)$ than during semester break (17.9 \pm 0.3 to $43.8 \pm 3.9 \mu \mathrm{g} / \mathrm{m}^{3}$ ) due to traffic [17]. In Sweden, investigation of indoor and outdoor levels of $\mathrm{NO}_{2}$ in schools by using diffusive samplers ranged from $2.9-47.0 \mu \mathrm{g} / \mathrm{m}^{3}$ (mean $17.3 \pm 12.5 \mu \mathrm{g} / \mathrm{m}^{3}$ ) and 1.7-50.9 $\mu \mathrm{g} / \mathrm{m}^{3}$ (mean $20.6 \pm 16.0 \mu \mathrm{g} / \mathrm{m}^{3}$ ), respectively. The main source of indoor $\mathrm{NO}_{2}$ at the school was between $64-71 \%$ of the outdoor $\mathrm{NO}_{2}$ infiltration [18]. Olufemi et al. [19] employed passive samplers to measure inside and outside $\mathrm{NO}_{2}$ concentrations the school, as well as in the surrounding vicinities of the coal mine, South Africa, which used to passive samplers. They reported that the levels of $\mathrm{NO}_{2}$ inside and outside were between $19-28 \mu \mathrm{g} / \mathrm{m}^{3}$ and 9.9-27 $\mu \mathrm{g} / \mathrm{m}^{3}$, respectively. Norbäck et al. [9] investigated indoor $\mathrm{NO}_{2}$ readings at Malaysian schools using a diffusion passive sampler. They found that $\mathrm{NO}_{2}$ levels of $23 \mu \mathrm{g} / \mathrm{m}^{3}$ were linked to ocular symptoms and weariness. Hence, children are more vulnerable to $\mathrm{NO}_{2}$ exposure than adults.

Numerous studies show significant associations between exposure to $\mathrm{NO}_{2}$ and the adverse health effects of children. For example, Zheng et al. [20] revealed that asthma emergency room visits and hospital admissions were more likely to be associated with $\mathrm{NO}_{2}$ exposure in children. Exposure to $\mathrm{NO}_{2}$ after 4 years of age might contribute to the development of asthma and this has been seen as asthma can be more reliably diagnosed [21]. Favarato et al. [6] reported ambient $\mathrm{NO}_{2}$ release from traffic pollution was associated with asthma prevalence in children, which could be oxidative stress/antioxidant depletion, increase inflammation and airway hyperresponsiveness, enhanced responses to allergens, and impacts on immunity. Song et al. [22] revealed the short-term association link between $\mathrm{NO}_{2}$ and eye and adnexa diseases (EADs), suggesting that $\mathrm{NO}_{2}$ generated by traffic could be considered as a useful bio-indicator of the harmful impacts of traffic-related air pollution exposure [23]. Moreover, Ayuni and Juliana [5] reported $\mathrm{NO}_{2}$ concentrations may increase the risk of respiratory illnesses and reduced lung function among elementary school children living close to petrochemical plants.

Based on the above facts, the researcher decided to determine firstly both indoor and outdoor $\mathrm{NO}_{2}$ concentrations and non-carcinogenic risk assessment in selected elementary schools in Rayong province. Secondly, to investigate the associations between the impacts of the determined pollutants on the health of the students. The physical signs included eye irritation, pink eye (allergic conjunctivitis), nasal congestion, runny nose, sore throat, rash in the face and the arms, faint, headache, fatigue, wheeze, and cough.

\section{Materials and Methods}

\subsection{Sampling Site}

Rayong province is located in the eastern part of Thailand. It is one of the industrial estates in Thailand. Moreover, Rayong is one of three eastern provinces (Chachoengsao, Chonburi, and Rayong) selected to participate in the Thailand's Eastern Economic Corridor's area-based development project (EEC). The EEC project has been planned as part of Thailand's 4.0 economic policy approach. The Maptaphut Industrial Estate is the main industrial estate in Rayong province, which was developed and began operations in 1989 and covers an area of 2,746.64 acres (shown in Fig. 1). The estate consists of 541 industrial plants, which include 6 coal-fired power plants, 148 petrochemical and chemical product plants, 7 petroleum plants, 2 oil refineries, 58 steel and metal factories, and 23 rubber processing plants [24].

The selected elementary schools are located in Rayong city municipality and Maptaphut municipality, Rayong province. There are forty-two elementary schools in downtown Rayong city. Eight elementary schools were randomly selected from 4 schools in Rayong city municipality and 4 schools in Maptaphut municipality as shown in Table S1 and Fig. 1. In each school, three classrooms of grade 1-6 students were randomly selected in each elementary school. The researchers selected based on the fact that these schools are close to industrial areas in Maptaphut municipality. Other elementary schools in Rayong city municipality are based on criteria of school roadside in a community area, traffic intensity, and transport networks.

\subsection{Collection of $\mathrm{NO}_{2}$ Samples and Analysis}

Indoor and outdoor $\mathrm{NO}_{2}$ samples were collected by lab-made polypropylene passive diffusion tubes $(7.70 \mathrm{~cm}$ length and $1.50 \mathrm{~cm}$ inner diameter) from Environmental Chemistry Research Laboratory (ECRL), Chemistry department, Faculty of Science, Chiang Mai University [25]. The passive sampler was contained $20 \%$ triethanolamine (TEA) on GF/A filter paper (5 sampling tubes and 3 blank tubes). Sampling has been continuously exposed for 7 days (one sample) from September 2018 to February 2019. After the sampling, the $\mathrm{NO}_{2}$ concentration was determined colourimetrically as nitrite $\left(\mathrm{NO}_{2}{ }^{-}\right)$. The samples were extracted by de-ionized water, Salzmann reagent, and $\mathrm{NO}_{2}$ concentrations were obtained 


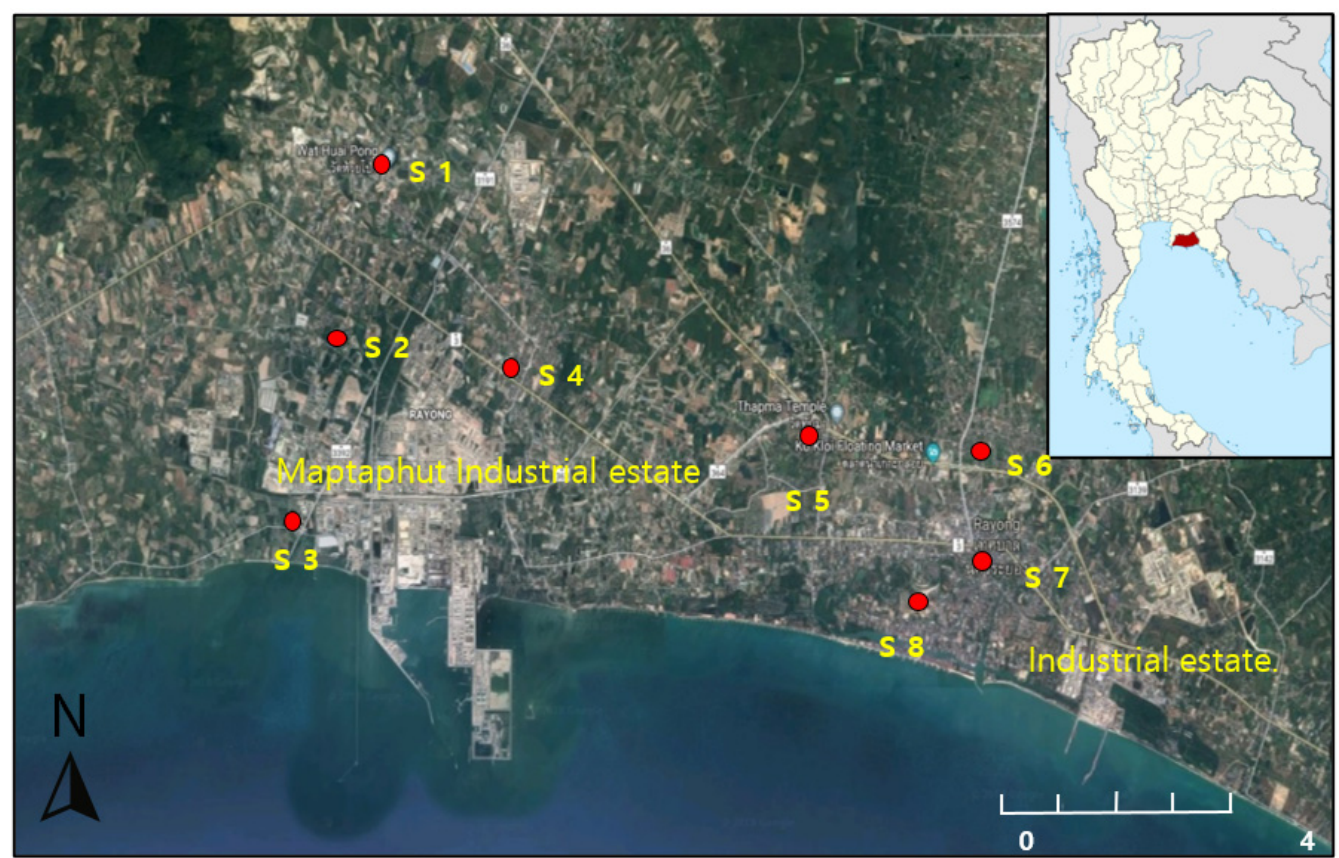

Fig. 1. Map of monitoring of $\mathrm{NO}_{2}$ values in elementary schools in Rayong province.(Applied from Googlemap)

from spectrophotometry (Shimadzu UV 2600, Japan) at $540 \mathrm{~nm}$. Spectrophotometry was used to measure the sample solutions with Salzmann reagent serving as blank. Detailed pre-treatment and analysis procedures for the quality control/quality assurance (QC/QA) of $\mathrm{NO}_{2}$ could be found the limit of detection (LOD) and limit of quantification (LOQ) were $0.005 \mathrm{mg} / \mathrm{L}\left(0.14 \mu \mathrm{g} / \mathrm{m}^{3}\right)$ and $0.015 \mathrm{mg} / \mathrm{L}\left(0.42 \mu \mathrm{g} / \mathrm{m}^{3}\right)$, respectively.

The passive sampling inside the classroom was placed 1.0-1.5 $\mathrm{m}$ above the floor level, while the outdoor sampling was placed 1.5-2.0 $\mathrm{m}$ above the ground level. One set of sampling was collected from each classroom and one set of outdoor sampling.

\subsection{Ethical Considerations}

The present study was reviewed and approved by the Chiang Mai University Research Ethics Committee, Chiang Mai University, Certificate of Ethical Clearance No. 60/052 (COA No.017/61), 23 March 2018.

\subsection{Questionnaire}

A total number of 721 students from grades 1 to 6 in the selected elementary schools in Rayong Province participated in this study. Of the total number of 4,336 students in Rayong City Municipality, 366 students were selected. Also, of the 2,944 students in Maptaphut Municipality, 355 students were selected (Rayong primary educational service area office 1). The number of selected students was calculated by the formula of Taro Yamane [26]. It's presented as Eq. (1).

$$
\mathrm{n}=\frac{\mathrm{N}}{1+\mathrm{Ne}^{2}}
$$

Where $\mathrm{n}$ is sample size required, $\mathrm{N}$ is the number of students in the population and e is the acceptable sampling error based on a 95\% confidence level and $p=0.5$

The questionnaire was given to all students in the selected classroom for the sampling of $\mathrm{NO}_{2}$ concentrations and answered at home together with student parents. When the students returned the questionnaires to their teacher. The questionnaire comprised questions on socio-demographic factors on age, gender, weight, height, academic level, residential area, and smoking at home. The questionnaire asked to elucidate the individual impacts of $\mathrm{NO}_{2}$ on 11 physical human health (symptoms) including ocular, nose, throat, dermal and general symptoms, which were shown in Table 5. Each question of symptoms had three alternative answers and was classified into three scores. The score of " 0 " was no or never, "1" if was the sometimes symptoms and the often symptoms indicated the score was "2". The survey was conducted from January to March 2019. The recall period was over six months. After retrieving these questionnaires, a total of 638 questionnaires were analyzed.

\subsection{Non-carcinogenic Risk Assessment}

This research calculated a health risk assessment from the hazard quotient (HQ) to evaluate non-carcinogenic risk exposure of $\mathrm{NO}_{2}$ $[3,19]$. The children's health risk assessment to $\mathrm{NO}_{2}$ exposure pathway was referred the exposure factor articulated by the United State Environmental Protection Agency: 2011 Edition [27]. The average daily dose (ADD) through inhalation can be calculated as shown in Eq. (2).

$$
\mathrm{ADD}=\frac{\mathrm{C} \times \operatorname{Inh} \mathrm{R} \times \mathrm{ET} \times \mathrm{EF} \times \mathrm{ED}}{\mathrm{BW} \times \mathrm{AT}}
$$

Where $\mathrm{ADD}$ is the $\mathrm{ADD}$ of pollutants [28]; $\mathrm{C}$ is the concentration of $\mathrm{NO}_{2}\left(\mu \mathrm{g} / \mathrm{m}^{3}\right)$; InhR is the inhalation rate $\left(\mathrm{m}^{3} / \mathrm{h}\right)$; ET is the exposure 
Table 1. Parameters of the Average Daily Dose (ADD) for $\mathrm{NO}_{2}$ [27]

\begin{tabular}{lcc}
\hline \multirow{2}{*}{ Parameters } & \multicolumn{2}{c}{ Exposed group } \\
\cline { 2 - 3 } & $\begin{array}{c}\text { Children } \\
\text { (6- }<\mathbf{1 1} \text { years) }\end{array}$ & $\begin{array}{c}\text { Teenagers } \\
(\mathbf{1 1}-<\mathbf{1 6} \text { years })\end{array}$ \\
\hline Inhalation rate (InhR) & $0.50 \mathrm{~m}^{3} / \mathrm{h}$ & $0.63 \mathrm{~m}^{3} / \mathrm{h}$ \\
$\left(12.0 \mathrm{~m}^{3} / \mathrm{d}\right)$ & $\left(15.2 \mathrm{~m}^{3} / \mathrm{d}\right)$ \\
Exposure frequency (EF) & $350 \mathrm{~d} /$ year & $350 \mathrm{~d} / \mathrm{year}$ \\
Exposure duration (ED) & 5 years & 5 years \\
Exposure time (ET) & $24 \mathrm{~h} / \mathrm{d}$ & $24 \mathrm{~h} / \mathrm{d}$ \\
Averaging time (AT) & $1,825 \mathrm{~d}$ & $1,825 \mathrm{~d}$ \\
AT = ED $\times 365 \mathrm{~d}$ & $31.8 \mathrm{Kg}$ & $56.8 \mathrm{Kg}$ \\
Bodyweight (BW) & \multicolumn{2}{c}{$1.1 \times 10^{-2} \mathrm{mg} / \mathrm{kg}-\mathrm{d}$} \\
\hline RfD & \multicolumn{2}{c}{}
\end{tabular}

time $(\mathrm{h} / \mathrm{d}) ; \mathrm{EF}$ is the exposure frequency (d/year); $\mathrm{ED}$ is the exposure duration (years); BW is the bodyweight of the exposed group (kg) and AT is the average time (d). The values of these parameters were shown in Table 1.

The HQ was calculated from the ratio of ADD and the reference dose (RfD) of each pollutant using the following Eq. (3).

$$
\mathrm{HQ}=\frac{\mathrm{ADD}}{\mathrm{RfD}}
$$

The reference concentrations (RfD) allowable for human exposure to $\mathrm{NO}_{2}$ is $1.1 \times 10^{-2} \mathrm{mg} / \mathrm{kg}-\mathrm{d}$ [29]. When the $\mathrm{HQ}<1.0$, there is no hazard or only negligible risks, while the HQ $>1.0$ indicates adverse non-carcinogenic effect concern [19].

\subsection{Data Analysis}

The determination of the difference between indoor and outdoor nitrogen dioxide levels in schools was statistically analyzed using the T-test. One-way ANOVA with Tukey test analyzed the mean $\mathrm{NO}_{2}$ difference between the sampling of elementary schools. Pearson correlation analysis was used to assess the relations between the inside and outside of $\mathrm{NO}_{2}$ concentrations.

The statistic of questionnaire data was analyzed using the Chi-squared test $\left(x^{2}\right)$ to study the association between indoor $\mathrm{NO}_{2}$ concentrations in elementary schools and demographics characteristics. Considering that these results present all variables to be statistically significant with a level of $p$-value below 0.05. Multiple logistic regression was used to determine the association between $\mathrm{NO}_{2}$ levels in classrooms and physical human health variables. Odds ratios (OR) with 95\% confidence intervals (95\% CI) were calculated using SPSS version 25. A $p$-value below 0.05 with two-tailed tests was indicated to be a significance level.

\section{Results and Discussion}

\section{1. $\mathrm{NO}_{2}$ Concentrations in Elementary Schools}

The average concentrations of indoor $\mathrm{NO}_{2}$ were measured in classrooms at elementary schools in Rayong city as shown in Table 2. Ranges of indoor $\mathrm{NO}_{2}$ concentrations in the eight elementary schools were $9.0 \pm 4.4$ to $16.7 \pm 2.7 \mu \mathrm{g} / \mathrm{m}^{3}$, while the values of outdoor were $8.2 \pm 2.1$ to $17.7 \pm 6.7 \mu \mathrm{g} / \mathrm{m}^{3}$. The highest indoor $\mathrm{NO}_{2}$ concentration was found at the S4 site $\left(16.7 \pm 2.7 \mu \mathrm{g} / \mathrm{m}^{3}\right)$, while the outdoor $\mathrm{NO}_{2}$ levels in the $\mathrm{S} 1$ site was the highest (17.7 $\pm 6.7 \mu \mathrm{g} / \mathrm{m}^{3}$ ). The cause of $\mathrm{NO}_{2}$ concentration in both sites is located close to a highway intersection with high traffic intensity and industrial area. In Spain, Villanueva et al. [10] reported the indoor and outdoor $\mathrm{NO}_{2}$ concentrations in primary school, which is situated in the industrial estate including refinery, chemical industry, two power plants, and a coal mine in Ciudad Real city. They found that the average of indoor $\mathrm{NO}_{2}$ concentrations were $13.4 \pm 2.5 \mu \mathrm{g} / \mathrm{m}^{3}\left(9.8-15.8 \mu \mathrm{g} / \mathrm{m}^{3}\right)$, while the values of outdoor were $6.0 \pm 2.2 \mu \mathrm{g} / \mathrm{m}^{3}\left(3.7-9.2 \mu \mathrm{g} / \mathrm{m}^{3}\right)$. Effect of traffic air pollution at schools in Barcelona, Spain, Rivas et al. [30] showed that the indoor and outdoor $\mathrm{NO}_{2}$ values in urban area were 5-69 $\mu \mathrm{g} / \mathrm{m}^{3}$ (Mean 30 $\pm 12 \mu \mathrm{g} / \mathrm{m}^{3}$ ) and 23-97 $\mu \mathrm{g} / \mathrm{m}^{3}$ (mean $41 \pm 15 \mu \mathrm{g} / \mathrm{m}^{3}$ ), respectively. However, the mean of indoor and outdoor $\mathrm{NO}_{2}$ concentrations in the industrial area at Rayong city found in this study was similar to those found inside primary schools in Spain, while those values were lower than in urban areas. Whereas when compared with studies from South Africa, for example as reported by Olufemi et al. [19], who conducted their study in five schools located close to the coal mines and coal-fired plants in Mpumalanga province. The result of their study revealed that the concentrations of $\mathrm{NO}_{2}$ both for indoor and outdoor were 19-28 and 9.9-27, respectively which were higher than the values reported in this present study (9.0-16.7 and $8.2-17.7 \mu \mathrm{g} / \mathrm{m}^{3}$, respectively). Norbäck et al. [9] reported indoor and outdoor concentrations in junior high school in Johor Bahru, Malaysia. It found that the levels of indoor and outdoor $\mathrm{NO}_{2}\left(17.0-32.3\right.$ and $\left.16.9-26.9 \mu \mathrm{g} / \mathrm{m}^{3}\right)$ were higher than those in this study $(9.0 \pm 4.4$ to $16.7 \pm 2.7$ and $8.2 \pm 2.1$ to $17.7 \pm 6.7 \mu \mathrm{g} / \mathrm{m}^{3}$ ). Moreover, Wichmann et al. [18] investigated that the indoor and outdoor $\mathrm{NO}_{2}$ concentrations in the primary schools of Stockholm, Sweden ranged between 2.9-47 and $1.7-50.9 \mu \mathrm{g} / \mathrm{m}^{3}$, respectively. The researchers of this study went further to expand that these high values were influenced by traffic emission. However, all the values of both indoor and outdoor $\mathrm{NO}_{2}$ complied with the recommended standard of guideline created by the National Ambient Air Quality Standard (NAAQS) and WHO $\left(<40 \mu \mathrm{g} / \mathrm{m}^{3}\right)$ [1].

The One-Way ANOVA was used to test the difference in the mean of $\mathrm{NO}_{2}$ concentrations between elementary schools. The measured $\mathrm{NO}_{2}$ concentrations were tested for the normal distribution (Shapiro-Wilk normality tests), in which the samples were normally distributed. It was found that the indoor $\mathrm{NO}_{2}$ concentrations in elementary schools at S1 and S4 sites were not significantly different ( $p>0.05$ ), but they were significantly different from those in all the other sites $(p<0.05)$. The outdoor $\mathrm{NO}_{2}$ concentrations measured in the $\mathrm{S} 1$ site were slightly higher than those sites. The highest $\mathrm{NO}_{2}$ concentration was found at the $\mathrm{S} 1$ site, which is situated in the industrial area. It is closely located to a tapioca flour manufactory and near an intersection. Ielpo et al. [13] investigated the spatial distributions of $\mathrm{NO}_{2}$ concentrations from a different source of $\mathrm{NO}_{2}$. They reported that the emission sources of $\mathrm{NO}_{2}$ were linked mainly to the traffic density and secondarily to the industrial source. Therefore, it might cause increased $\mathrm{NO}_{2}$ contamination in classrooms. The lowest value of indoor $\mathrm{NO}_{2}$ concentrations was 
Table 2. Indoor and Outdoor $\mathrm{NO}_{2}$ Concentrations $\left(\mu \mathrm{g} / \mathrm{m}^{3}\right)$ from Eight Elementary Schools in September 2018 to February 2019

\begin{tabular}{|c|c|c|c|c|c|c|c|c|c|c|}
\hline \multirow{2}{*}{ School } & \multicolumn{4}{|c|}{ Indoor $^{\mathrm{A}}\left(\mu \mathrm{g} / \mathrm{m}^{3}\right) \mathrm{n}=57$} & \multicolumn{4}{|c|}{ Outdoor $^{A}\left(\mu \mathrm{g} / \mathrm{m}^{3}\right) \mathbf{n}=19$} & \multirow{2}{*}{$\mathbf{I} / \mathbf{O}$} & \multirow{2}{*}{ I-O correlation } \\
\hline & Max & Min & mean & SD & Max & Min & mean & SD & & \\
\hline S1 & 22.3 & 6.6 & $15.5^{\mathrm{a}}$ & 5.1 & 29.3 & 3.9 & $17.7^{\mathrm{a}}$ & 6.7 & 0.87 & $0.845^{* *}$ \\
\hline S2 & 16.5 & 3.2 & $9.0^{\mathrm{b}}$ & 4.4 & 19.7 & 4.5 & $10.3^{\mathrm{b}}$ & 4.6 & 0.87 & $0.836^{* *}$ \\
\hline S3 & 16.6 & 6.0 & $10.6^{\mathrm{b}}$ & 3.4 & 11.5 & 5.3 & $8.2^{\mathrm{b}}$ & 2.1 & 1.29 & 0.373 \\
\hline S4 & 20.7 & 11.8 & $16.7^{\mathrm{a}}$ & 2.7 & 23.1 & 4.1 & $13.0^{\mathrm{C}}$ & 4.9 & 1.28 & 0.202 \\
\hline S5 & 18.7 & 4.9 & $11.6^{\mathrm{b}}$ & 4.6 & 25.0 & 5.4 & $13.3^{\mathrm{c}}$ & 6.1 & 0.87 & $1.000^{* *}$ \\
\hline S6 & 17.8 & 7.3 & $11.4^{\mathrm{b}}$ & 2.7 & 20.5 & 8.2 & $12.8^{\mathrm{c}}$ & 3.0 & 0.89 & $0.744^{* *}$ \\
\hline S7 & 16.8 & 4.2 & $11.5^{\mathrm{b}}$ & 3.6 & 21.0 & 4.8 & $12.4^{\mathrm{C}}$ & 4.7 & 0.92 & 0.910 ** \\
\hline S8 & 14.3 & 4.5 & $9.9^{\mathrm{b}}$ & 3.2 & 23.1 & 4.9 & $14.0^{\mathrm{d}}$ & 6.2 & 0.71 & $0.723^{* *}$ \\
\hline
\end{tabular}

Notes; $\mathrm{n}=$ Number of weeks $(\times 3$ classrooms) for indoor sampling, $\mathrm{A}=$ Range of significant discrepancy $(\mathrm{p}<0.05)$ among clusters of collecting areas. (horizontal direction), a, b, c, d = Range of significant discrepancy $(\mathrm{p}<0.05)$ among clusters of sampling sites (vertical direction), ${ }^{* *}$ Correlation is significant at the 0.01 level (2- tailed)

at the S2 site. It's a well-known fact that this site is located in an industrial area and surrounded by governmental offices (Table S1). Because of the advantage of building material, the classrooms were built with wooden materials in the fact that there is a lower input of contaminants. The reason for this is that there is adequate ventilation. There is no forced ventilation in all the schools, thus ventilation is done by opening doors and windows. There was sufficient natural ventilated [8]. Furthermore, the major of wind direction in Rayong province was north-northeast from October 2018 to January 2019, which was winter season influenced to the northeast monsoon in Thailand. Not only the wind direction but also wind speed was low speed during the sampling period (1.24$1.63 \mathrm{~m} / \mathrm{s}$ ) as shown in Fig. S1. According to Chithra and Shiva [31], the low wind speed and calm conditions indicated that air pollution had accumulated. $\mathrm{NO}_{2}$ levels in Rayong province were found to be unaffected by wind direction. As a result, local activities such as traffic intensity and industry may influence $\mathrm{NO}_{2}$ concentrations.

The concentrations of $\mathrm{NO}_{2}$ indoor classrooms were compared with the classrooms outdoor of elementary schools in Rayong city. It was found that the concentrations of $\mathrm{NO}_{2}$ obtained outdoors $\left(8.2 \pm 2.1\right.$ to $\left.17.7 \pm 6.7 \mu \mathrm{g} / \mathrm{m}^{3}\right)$ was slightly higher than indoors (9.0 \pm 4.4 to $\left.16.7 \pm 2.7 \mu \mathrm{g} / \mathrm{m}^{3}\right)$. However, the average $\mathrm{NO}_{2}$ concentrations between indoors and outdoors were tested using a T-test, there was not a significant difference in the findings $(p>0.05)$. In general, the study of the influence of outdoor air might be related to the observed indoor $\mathrm{NO}_{2}$ values, which could be supported by the inexistence of indoor sources by the indoor/outdoor (I/O) ratio results. The I/O ratios lower than 1 indicated that lower concentrations were observed indoors. The $\mathrm{I} / \mathrm{O}$ ratios of $\mathrm{NO}_{2}$ concentrations in this study ranged from 0.71-1.29 (Table 2). A study conducted around some schools in Stockholm, Sweden reported that the range of $\mathrm{I} / \mathrm{O}$ ratio of $\mathrm{NO}_{2}$ was $0.44-2.17$ [18]. The study of Norbäck et al. [9] revealed the $\mathrm{NO}_{2} \mathrm{I} / \mathrm{O}$ ratios $(0.80$ 1.59) at eight junior high schools in Malaysia were higher than this study. Moreover, Pearson's rank-correlation was calculated in influence to associate the $\mathrm{NO}_{2}$ concentrations between indoor and outdoor (I-O) in elementary schools were shown in Table 2. The largest part of indoor $\mathrm{NO}_{2}$ concentrations in elementary schools was significantly correlated $(p<0.01)$ with concen- trations of outdoor except for S3 and S4 sites. Because of accumulated $\mathrm{NO}_{2}$ from nearby industry and traffic congestion, $\mathrm{NO}_{2}$ levels within classrooms were found to be higher than outdoors for S3 and S4 sites. The strong positive correlations between indoor and outdoor $\mathrm{NO}_{2}$ concentrations were 0.723-1.000. The major cause of high $\mathrm{NO}_{2}$ concentrations indoors is as a result of emissions of $\mathrm{NO}_{2}$ from the outdoor environments such as traffic as confirmed by Nunes et al. [11]. Moreover, it was revealed in the study of Wichmann et al. [18] that the main source of indoor $\mathrm{NO}_{2}$ at schools was $64-71 \%$ of outdoor infiltrated indoor. It may be concluded that schools that are in proximity close to industrial plants and high traffic intensity are exposed to $\mathrm{NO}_{2}$ which may negatively affect the health of the students.

\subsection{Non-Carcinogenic Risk Assessment for $\mathrm{NO}_{2}$ Concentrations}

The results of the calculation for children's health risks from inhalation of indoor and outdoor $\mathrm{NO}_{2}$ are presented in Table 3. The mean $\mathrm{HQ}$ values of indoor $\mathrm{NO}_{2}$ exposure for children $(6-<11$ years) and teenagers (11- $<16$ years) at elementary schools in Rayong city ranged $0.30 \pm 0.14$ to $0.55 \pm 0.09$ and $0.20 \pm 0.10$ to $0.39 \pm 0.06$, while the outdoor $\mathrm{HQ}$ values for $\mathrm{NO}_{2}$ inhalation were $0.27 \pm 0.07$ to $0.58 \pm 0.22$ and $0.19 \pm 0.05$ to $0.41 \pm 0.16$, respectively. $\mathrm{HQ}$ for $\mathrm{NO}_{2}$ exposure of both indoor and outdoor was less than 1.0, which is indicated no significant risk occurs. Moreover, all values of HQ for children and teenagers at elementary schools in Rayong city were less than 1.0. This finding isn't considered a threat risk. Therefore, the non-carcinogenic risk assessment for inhalation of indoor and outdoor $\mathrm{NO}_{2}$ in elementary schools in Rayong city implied a negligible risk. Olufemi et al. [19] reported in their study that the HQ values for $\mathrm{NO}_{2}$ exposure in four schools in the vicinities of coal mines, South Africa were 0.001-0.002 for inside and 0.0007-0.0019 for outside, which was lower than what was reported in this study. However, the previous health risk studies have reported that even inhalation of a small quantity of $\mathrm{NO}_{2}$ might increase the risks of hospitalizations, asthma problems and rhinoconjunctivitis, respiratory problems, ocular symptoms, fatigue and decreased lung function in children [9, 20, 21, 32]. Flores-Pajot et al. [33] revealed that an increase of 10 ppb in $\mathrm{NO}_{2}$ during pregnancy was associated with an increased risk of autism. Zhang et al. [32] studied the association of the 
Table 3. Non-carcinogenic Health risk for $\mathrm{NO}_{2}$ Inhalation by Child and Adults

\begin{tabular}{|c|c|c|c|c|c|c|c|c|}
\hline \multirow{3}{*}{ Schools } & \multicolumn{4}{|c|}{ Indoor } & \multicolumn{4}{|c|}{ Outdoor } \\
\hline & \multicolumn{2}{|c|}{$\begin{array}{c}\text { Children } \\
\text { (6- }<11 \text { year) }\end{array}$} & \multicolumn{2}{|c|}{$\begin{array}{c}\text { Teenagers } \\
(11-<16 \text { year })\end{array}$} & \multicolumn{2}{|c|}{$\begin{array}{c}\text { Children } \\
\text { (6- < } 11 \text { year) }\end{array}$} & \multicolumn{2}{|c|}{$\begin{array}{c}\text { Teenagers } \\
(11-<16 \text { year })\end{array}$} \\
\hline & $\begin{array}{c}\text { ADD } \\
\text { (min-max) }\end{array}$ & $\begin{array}{c}\text { HQ } \\
\text { (min-max) }\end{array}$ & $\begin{array}{c}\text { ADD } \\
\text { (min-max) }\end{array}$ & $\begin{array}{c}\text { HQ } \\
\text { (min-max) }\end{array}$ & $\begin{array}{c}\text { ADD } \\
\text { (min-max) }\end{array}$ & $\begin{array}{c}\text { HQ } \\
\text { (min-max) }\end{array}$ & $\begin{array}{c}\text { ADD } \\
\text { (min-max) }\end{array}$ & $\begin{array}{c}\text { HQ } \\
\text { (min-max) }\end{array}$ \\
\hline S1 & $\begin{array}{l}5.26 \pm 1.85 \\
(2.40-8.08)\end{array}$ & $\begin{array}{c}0.51 \pm 0.17 \\
(0.22-0.73)\end{array}$ & $\begin{array}{l}3.96 \pm 1.31 \\
(1.69-5.70)\end{array}$ & $\begin{array}{l}0.36 \pm 0.12 \\
(0.15-0.52)\end{array}$ & $\begin{array}{c}6.41 \pm 2.43 \\
(1.42-10.62)\end{array}$ & $\begin{array}{l}0.58 \pm 0.22 \\
(0.13-0.97)\end{array}$ & $\begin{array}{l}4.52 \pm 1.72 \\
(1.00-7.49)\end{array}$ & $\begin{array}{l}0.41 \pm 0.16 \\
(0.09-0.69)\end{array}$ \\
\hline S2 & $\begin{array}{l}3.26 \pm 1.57 \\
(1.14-5.98)\end{array}$ & $\begin{array}{l}0.30 \pm 0.14 \\
(0.10-0.54)\end{array}$ & $\begin{array}{l}2.30 \pm 1.11 \\
(0.81-4.22)\end{array}$ & $\begin{array}{l}0.20 \pm 0.10 \\
(0.07-0.38)\end{array}$ & $\begin{array}{l}3.73 \pm 0.87 \\
(1.64-7.12)\end{array}$ & $\begin{array}{l}0.34 \pm 0.15 \\
(0.15-0.65)\end{array}$ & $\begin{array}{l}2.63 \pm 1.17 \\
(1.16-5.02)\end{array}$ & $\begin{array}{l}0.24 \pm 0.11 \\
(0.11-0.46)\end{array}$ \\
\hline S3 & $\begin{array}{l}3.82 \pm 1.23 \\
(2.17-6.02)\end{array}$ & $\begin{array}{l}0.35 \pm 0.11 \\
(0.20-0.55)\end{array}$ & $\begin{array}{l}2.70 \pm 0.87 \\
(1.53-4.25)\end{array}$ & $\begin{array}{l}0.25 \pm 0.08 \\
(0.14-0.39)\end{array}$ & $\begin{array}{c}2.96 \pm 0.76 \\
(1.91-4.17)\end{array}$ & $\begin{array}{l}0.27 \pm 0.07 \\
(0.17-0.38)\end{array}$ & $\begin{array}{l}2.09 \pm 0.54 \\
(1.35-2.94)\end{array}$ & $\begin{array}{l}0.19 \pm 0.05 \\
(0.12-0.27)\end{array}$ \\
\hline S4 & $\begin{array}{l}6.03 \pm 0.98 \\
(4.28-7.50)\end{array}$ & $\begin{array}{l}0.55 \pm 0.09 \\
(0.39-0.68)\end{array}$ & $\begin{array}{l}4.25 \pm 0.69 \\
(3.02-5.29)\end{array}$ & $\begin{array}{l}0.39 \pm 0.06 \\
(0.27-0.48)\end{array}$ & $\begin{array}{l}4.68 \pm 1.76 \\
(1.50-8.36)\end{array}$ & $\begin{array}{l}0.43 \pm 0.16 \\
(0.14-0.43)\end{array}$ & $\begin{array}{l}3.30 \pm 1.24 \\
(1.06-5.89)\end{array}$ & $\begin{array}{l}0.30 \pm 0.11 \\
(0.12-0.27)\end{array}$ \\
\hline S5 & $\begin{array}{l}4.19 \pm 1.66 \\
(1.78-6.76)\end{array}$ & $\begin{array}{l}0.38 \pm 0.15 \\
(0.16-0.61)\end{array}$ & $\begin{array}{l}2.96 \pm 1.17 \\
(1.25-4.77)\end{array}$ & $\begin{array}{c}0.27 \pm 0.11 \\
(0.11-0.43)\end{array}$ & $\begin{array}{c}4.82 \pm 2.22 \\
(1.95-9.06)\end{array}$ & $\begin{array}{l}0.44 \pm 0.20 \\
(0.18-0.82)\end{array}$ & $\begin{array}{l}3.42 \pm 1.57 \\
(1.38-6.43)\end{array}$ & $\begin{array}{l}0.31 \pm 0.14 \\
(0.13-0.58)\end{array}$ \\
\hline S6 & $\begin{array}{l}4.13 \pm 0.98 \\
(2.64-6.46)\end{array}$ & $\begin{array}{l}0.38 \pm 0.09 \\
(0.24-0.59)\end{array}$ & $\begin{array}{l}2.91 \pm 0.69 \\
(1.86-4.56)\end{array}$ & $\begin{array}{l}0.26 \pm 0.06 \\
(0.17-0.41)\end{array}$ & $\begin{array}{c}4.63 \pm 1.08 \\
(2.97-7.43)\end{array}$ & $\begin{array}{l}0.42 \pm 0.10 \\
(0.27-0.68)\end{array}$ & $\begin{array}{l}3.28 \pm 0.77 \\
(2.11-5.27)\end{array}$ & $\begin{array}{l}0.30 \pm 0.07 \\
(0.19-0.48)\end{array}$ \\
\hline S7 & $\begin{array}{l}4.15 \pm 1.30 \\
(1.53-6.08)\end{array}$ & $\begin{array}{l}0.38 \pm 0.12 \\
(0.14-0.55)\end{array}$ & $\begin{array}{l}2.93 \pm 0.91 \\
(1.08-4.29)\end{array}$ & $\begin{array}{l}0.27 \pm 0.08 \\
(0.10-0.39)\end{array}$ & $\begin{array}{l}4.49 \pm 1.69 \\
(1.72-7.59)\end{array}$ & $\begin{array}{l}0.41 \pm 0.15 \\
(0.16-0.69)\end{array}$ & $\begin{array}{l}3.18 \pm 1.20 \\
(1.22-5.38)\end{array}$ & $\begin{array}{l}0.29 \pm 0.11 \\
(0.11-0.49)\end{array}$ \\
\hline S8 & $\begin{array}{l}3.57 \pm 1.15 \\
(1.63-5.19)\end{array}$ & $\begin{array}{l}0.32 \pm 0.10 \\
(0.15-0.47)\end{array}$ & $\begin{array}{l}2.52 \pm 0.81 \\
(1.15-3.66)\end{array}$ & $\begin{array}{l}0.23 \pm 0.07 \\
(0.10-0.33)\end{array}$ & $\begin{array}{l}5.05 \pm 2.23 \\
(1.76-8.35)\end{array}$ & $\begin{array}{l}0.46 \pm 0.20 \\
(0.16-0.76)\end{array}$ & $\begin{array}{l}3.58 \pm 1.58 \\
(1.25-5.92)\end{array}$ & $\begin{array}{l}0.33 \pm 0.14 \\
(0.11-0.54)\end{array}$ \\
\hline
\end{tabular}

Note; ADD $=\mu \mathrm{g} / \mathrm{kg}-\mathrm{d}$

long-term mortality effect on chronic obstructive pulmonary disease (COPD) and $\mathrm{NO}_{2}$ concentration. They revealed that consistent evidence of the potential positive association between $\mathrm{NO}_{2}$ and COPD risk. An increase of $10 \mu \mathrm{g} / \mathrm{m}^{3}$ in $\mathrm{NO}_{2}$ concentration has been contributed towards an increase of $2.0 \%$ in associated COPD in adults and an increase of $1.3 \%$ in hospital admissions and an increase of $2.6 \%$ in mortality.

\subsection{Associations between Indoor $\mathrm{NO}_{2}$ Exposure and Health of Students at Elementary Schools in Rayong City}

\subsubsection{Socio-demographics characteristics and symptoms}

The gender of students was 325 boys (50.9\%) and 313 girls (49.1\%). The mean age was 9.7 years old and height $120.3 \mathrm{~cm}$. A total of $43.9 \%$ was lived in the urban area (central town), $26.5 \%$ in the industrials area, and $25.7 \%$ in a sub-urban area, and $3.9 \%$ in the rural area as shown in Table 4. The socio-demographic characteristics of gender, age, height, urban area, sub-urban area, rural area and smoking at home were not significantly associated with $\mathrm{NO}_{2}$ values in classrooms $(p>0.05)$. However, the industrial area was significantly associated with $\mathrm{NO}_{2}$ concentrations $(p<$ 0.05). The prevalence is the percentage of student in a population who have a particular symptom or trait at a given time or throughout a specific period of times, calculating the following Eq. (S1). The prevalence proportion of physical human health (symptoms) from students in elementary schools was shown in Table 5. The highest prevalence of symptoms in students was found the runny nose (89.2\%), which was followed by cough (88.1\%), nasal congestion $(80.6 \%)$, sore throat $(71.6 \%)$, headache $(59.9 \%)$ and eye irritation (59.4\%), respectively.
Table 4. Socio-demographics Characteristics and Associations between $\mathrm{NO}_{2}$ Concentrations in Classrooms and Gender, Residential Areas, and Smoking

\begin{tabular}{lcccc}
\hline Characteristics $(\mathbf{N}=\mathbf{6 3 8})$ & $\mathbf{n}$ & $\mathbf{\%}$ & $x^{2}$ & $\boldsymbol{p}$-Value \\
\hline Gender & & & & \\
Boys & 325 & 50.9 & 2.561 & 0.452 \\
Girls & 313 & 49.1 & & \\
Age (6-15 years) & 9.7 & & 2.085 & 0.615 \\
Height (110-120 cm) & 120.3 & & 4.286 & 0.186 \\
Residential area & & & & \\
Urban area (downtown) & 280 & 43.9 & 1.154 & 0.052 \\
Industrial area & 169 & 26.5 & 3.746 & $\mathbf{0 . 0 4 8}$ \\
Sub-urban area & 164 & 25.7 & 2.496 & 0.079 \\
Rural area & 25 & 3.9 & 2.859 & 0.084 \\
Smoking at home & & & & \\
Yes & 293 & 45.9 & 3.484 & 0.127 \\
No & 345 & 54.1 & & \\
\hline
\end{tabular}

Note; Bolds represent statistically significant with a level of $p$-value $<0.05$

\subsubsection{Associations between $\mathrm{NO}_{2}$ exposure and physical human} health in classrooms

Exposure to $\mathrm{NO}_{2}$ in classrooms could be related to health risks. Table 5 presents the association between exposure to the indoor $\mathrm{NO}_{2}$ concentrations and the physical human health of students in classrooms. It found that the indoor $\mathrm{NO}_{2}$ was associated with 
Table 5. The Logistic Regression for Associations between $\mathrm{NO}_{2}$ in Classrooms and Physical Human Health from Students $(\mathrm{n}=638)$ in Elementary Schools

\begin{tabular}{|c|c|c|c|c|c|c|c|c|c|}
\hline \multirow{2}{*}{ Gender } & \multicolumn{2}{|c|}{ Often } & \multicolumn{2}{|c|}{ Sometimes } & \multicolumn{2}{|c|}{ Never } & \multirow{2}{*}{$\begin{array}{l}\text { \% Prevalence of symptoms } \\
\text { from students }\end{array}$} & \multirow{2}{*}{$\begin{array}{c}\text { OR } \\
(95 \% \mathrm{CI})\end{array}$} & \multirow{2}{*}{$p$-Value } \\
\hline & $\mathbf{n}$ & $\%$ & $\mathbf{n}$ & $\%$ & $\mathbf{n}$ & $\%$ & & & \\
\hline \multicolumn{10}{|c|}{ Eye irritation (dry eye and itching eye) } \\
\hline Boys & 25 & 54.3 & 163 & 48.9 & 137 & 52.9 & \multirow{2}{*}{59.4} & 2.64 & \multirow{2}{*}{0.007} \\
\hline Girls & 21 & 45.7 & 170 & 51.1 & 122 & 47.1 & & $(0.42-4.76)$ & \\
\hline \multicolumn{10}{|c|}{ Pink eye/ allergic conjunctivitis } \\
\hline Boys & 6 & 85.7 & 96 & 59.3 & 223 & 47.5 & \multirow{2}{*}{26.5} & 2.14 & \multirow{2}{*}{0.012} \\
\hline Girls & 1 & 14.3 & 66 & 40.7 & 246 & 52.4 & & $(0.63-7.18)$ & \\
\hline \multicolumn{10}{|c|}{ Runny nose } \\
\hline Boys & 86 & 55.5 & 197 & 47.6 & 42 & 60.9 & \multirow{2}{*}{89.2} & 3.52 & \multirow{2}{*}{0.020} \\
\hline Girls & 69 & 44.5 & 217 & 52.4 & 27 & 39.1 & & $(1.26-9.42)$ & \\
\hline \multicolumn{10}{|c|}{ Nasal congestion } \\
\hline Boys & 77 & 52.7 & 176 & 47.8 & 72 & 58.1 & \multirow{2}{*}{80.6} & 1.20 & \multirow{2}{*}{0.627} \\
\hline Girls & 69 & 47.3 & 192 & 52.2 & 52 & 41.9 & & $(0.50-3.86)$ & \\
\hline \multicolumn{10}{|c|}{ Sore throat } \\
\hline Boys & 66 & 55.5 & 166 & 49.1 & 93 & 51.4 & \multirow{2}{*}{71.6} & 1.46 & \multirow{2}{*}{0.038} \\
\hline Girls & 53 & 44.5 & 172 & 50.9 & 88 & 48.6 & & $(0.82-4.52)$ & \\
\hline \multicolumn{10}{|c|}{ Rash in the face/ in the arms } \\
\hline Boys & 20 & 60.6 & 91 & 50.6 & 214 & 50.4 & \multirow{2}{*}{33.4} & 2.45 & \multirow{2}{*}{0.577} \\
\hline Girls & 13 & 39.4 & 89 & 49.4 & 211 & 49.6 & & $(0.82-4.66)$ & \\
\hline \multicolumn{10}{|l|}{ Faint } \\
\hline Boys & 0 & 0 & 19 & 47.5 & 306 & 51.5 & \multirow{2}{*}{6.9} & 3.84 & 0 \\
\hline Girls & 4 & 100 & 21 & 52.5 & 288 & 48.5 & & $(1.62-7.42)$ & 0.865 \\
\hline Headacl & & & & & & & & & \\
\hline Boys & 26 & 46.4 & 168 & 51.5 & 131 & 51.2 & 50 & 1.76 & 0021 \\
\hline Girls & 30 & 53.6 & 158 & 48.5 & 125 & 48.8 & 59.9 & $(0.72-8.15)$ & 0.621 \\
\hline Wheeze & & & & & & & & & \\
\hline Boys & 25 & 52.1 & 114 & 52.3 & 186 & 50 & 7 & 0.86 & 0029 \\
\hline Girls & 23 & 47.9 & 104 & 47.7 & 186 & 50 & 41.7 & $(0.28-3.12)$ & 0.022 \\
\hline Fatigue & & & & & & & & & \\
\hline Boys & 40 & 57.1 & 122 & 48.6 & 163 & 51.4 & $50 ?$ & 0.97 & 0900 \\
\hline Girls & 30 & 42.9 & 129 & 51.4 & 154 & 48.6 & 50.3 & $(0.48-2.94)$ & 0.698 \\
\hline Cough & & & & & & & & & \\
\hline Boys & 84 & 56.8 & 205 & 49.5 & 36 & 47.4 & 801 & 1.66 & 0025 \\
\hline Girls & 64 & 43.2 & 209 & 50.5 & 40 & 52.6 & 88.1 & $(0.82-3.42)$ & 0.035 \\
\hline
\end{tabular}

Note: Bolds represent statistically significant with a level of $p$-value $<0.05$

prevalence of student symptoms including eye irritation (OR 2.64, 95\%CI 0.42-4.76, $p$-value $=0.007$ ), pink eye/ allergic conjunctivitis (OR 2.14, 95\%CI 0.63-7.18, $p$-value $=0.012$ ), runny nose (OR 3.52, 95\%CI 1.26-9.42, $p$-value $=0.020$ ), sore throat (OR 1.46, 95\%CI $0.82-4.52, p$-value $=0.038$ ), wheeze (OR 0.86, 95\%CI 0.28-3.12, $\mathrm{p}$-value $=0.022$ ) and cough (OR 1.66, 95\%CI 0.82-3.42, $p$-value $=0.035$ ). Moreover, an odds ratio is a measure of relationship between these two properties' the presence or absence. According to odds ratio explanation, the probability of symptomatic eye irritation in student exposure to $\mathrm{NO}_{2}$ was assessed to be 2.64 times the odds of asymptomatic eye irritation. The 95\% confidence interval for this odds ratio was between 0.42 to 4.76 . The interval was rather wide because the numbers of students with asymptomatic eye irritation were low, etc.

The previous study on associations between indoor $\mathrm{NO}_{2}$ exposure and symptoms of students in primary schools was a significant variable. Norbäck et al. [9] revealed that $\mathrm{NO}_{2}$ in classrooms was associated with dry eyes or itching in the eyes (OR 2.34, 95\%CI 1.40-3.90, $p$-value $=0.001$ ) and fatigue (OR 1.67, 95\%CI 1.12-2.47, $p$-value $=0.010$ ). Song et al. [22] investigated the short-term association between $\mathrm{NO}_{2}$ and the risk of eye and adnexa diseases in Xinxiang, China. It found that exposure to $\mathrm{NO}_{2}$ was strongly associated with keratitis, which can increase the risk of hospital outpatients with eye and adnexa diseases. The 10-ppb increase of $\mathrm{NO}_{2}$ was related to an additional $6.8-7.5 \%$ of dry eye occurrence [34]. Navaes et al. [23] suggested that ocular discomfort symptoms and tear breakup 
time may be a bioindicator of the adverse health risk of traffic-derived $\mathrm{NO}_{2}$ exposure. It is well-known that $\mathrm{NO}_{2}$ can react with water vapour to form nitric acid, which might be the mechanism of the health effects of traffic exhaust fumes. Thailand is a tropical country with high air humidity [9]. Moreover, Javis et al. [35] reported that indoor $\mathrm{NO}_{2}$ was reacted moisture on the surface to the formation of nitrous acid (HONO), which can relate to a decline in lung function and respiratory problems. Several researchers reported that $\mathrm{NO}_{2}$ exposure of children can be associated with problems such as eczema, current wheeze, sore throat, and current rhinitis [4-6, 36]. Therefore, our study of the exposure to $\mathrm{NO}_{2}$ in classrooms found that this harmed children's health, which was found to come from high traffic intensity and the industrial estate. According to Khamyingkert and Thepanondh [37], the petrochemical industry group in Maptaput industrial estates produced the highest annual average $\mathrm{NO}_{2}$ concentrations of $67.23 \%$, followed by power plant industry group with $28.23 \%$. Moreover, the daily number of vehicles passing through the highway road (NH36) was manually counted and estimated to be around 50,400 cars (Rayong city).

\section{Conclusions}

Based on the results of this study, it is concluded that the indoor $\mathrm{NO}_{2}$ concentrations in elementary schools in the vicinity of the industrial estate in Rayong city are caused by emissions from traffics and industrial plants. It was observed that $\mathrm{NO}_{2}$ values inside classrooms were strongly correlated with outdoor pollution conditions. Non-carcinogenic risk assessment of $\mathrm{NO}_{2}$ was used to assess the health risk of students in elementary was found that the HQ of all studied in elementary school was less than 1, revealing no health risk for children and teenagers. However, indoor $\mathrm{NO}_{2}$ concentrations in elementary schools could pose a significant risk to physical human health, with symptoms such as eye irritation, pink eye/ allergic conjunctivitis, runny nose, sore throat, wheeze and cough being among the most common in students. Therefore, children who spend time in classrooms at schools located near heavy traffic and petrochemical plant are most likely to suffer from related health problems.

\section{Acknowledgments}

The authors are grateful to the Faculty of Science, Energy, and Environment, King Mongkut's University of Technology North Bangkok. This research was funded by King Mongkut's University of Technology North Bangkok, Contract no. KMUTNB-64-KNOW16. The authors also wish to thank all officers of Rayong city and Maptaphut municipality and teachers at selected elementary schools in Rayong province. We greatly appreciate Thailand's Pollution Control Department (PCD) and Asst. Prof. Dr. Prapat Pongkiatkul support with wind direction and speed data for the wind rose model (version: 1.00-210911).

\section{Author Contributions}

Dr. S.B. (Assistant Professor) has been involved in the design of work including conceptualization, methodology, writing- review \& editing, visualization, supervision, and funding for this research work. Dr. S.P. (Lecturer/Research Assistant) designed the experiment for formal analysis, data management, software, statistical analysis, and interpretation, which was ensured the accuracy and completeness of this work's results. Also, we were jointly reviewed and edited drafting work content until the job was completed for publishing. We have read and approved the final manuscript.

\section{References}

1. World Health Organization (WHO). Ambient air pollution: A global assessment of exposure and burden of disease. [Internet] Geneva, Switzerland; 2016 [Cited 1 July 2020]. Available from https://apps.who.int/iris/handle/10665/250141.

2. World Health Organization (WHO). Air pollution and child health: prescribing clean air. WHO no. WHO/CED/PHE/18.01. [Internet] Geneva, Switzerland; 2018 [Cited 1 July 2020]. Available from https:/www.who.int/ceh/publications/air- pollution-child-health/en/.

3. Sun J and Zhou T. Health risk assessment of China's main air pollutants. BMC Public Health 2017;17:212:1-14.

4. Gül H, Gaga EO, Döğeroğlu T, et al. Respiratory health symptoms among students exposed to different levels of air pollution in a Turkish city. Int. J. Environ. Res. Public Health 2011;8:11101125.

5. Ayuni NA.and Juliana J. Exposure to $\mathrm{PM}_{10}$ and $\mathrm{NO}_{2}$ and association with respiratory health among primary school children living near petrochemical industry area at Kertih, Terengganu. J Med Biol Eng 2014;3(4):282-287.

6. Favarato G, Anderson HR, Atkinson R, Fuller G, Mills I, Walton $\mathrm{H}$. Traffic-related pollution and asthma prevalence in children. Quantification of associations with nitrogen dioxide. Air Qual. Atmos. Health 2014;7:459-466.

7. Gupta S. Exposure assessment of pulmonary functions of school-going children due to agriculture crop residue burning practice in Indo-Gangetic plains of India. Hum. Ecol. risk Assess. 2019;26(3):843-858.

8. Freitas MdC, Canha N, Martinho M, et al. Advanced topics in environmental health and air pollution case studies. Indoor air quality in primary schools. $1^{\text {st }}$ ed. Rijeka, Croatia: In Tech (Eds.) Press; 2011. p. 361-384.

9. Norbäck D, Hashim JH, Hashim Z, Ali F. Volatile organic compounds (VOC), formaldehyde and nitrogen dioxide $\left(\mathrm{NO}_{2}\right)$ in schools in Johor Bahru, Malaysia: Associations with rhinitis, ocular, throat and dermal symptoms, headache and fatigue. Sci. Total Environ. 2017;592:153-160.

10. Villanueva F, Tapia A, Lara S, Amo-Salas M. Indoor and outdoor air concentrations of volatile organic compounds and $\mathrm{NO}_{2}$ in schools of urban, industrial, and rural areas in Central-Southern Spain. Sci. Total Environ. 2018;622-623:222-235.

11. Nunes RAO, Branco PTBS, Alvim-Ferraz MCM, Martins FG, Sousa SIV. Gaseous pollutions on rural and urban nursery schools in Northern Portugal. Environ. Pollut. 2016;208:2-15.

12. Gokul Raj M, Karthikeyan S. Effect of modes of transportation on commuters' exposure to fine particulate matter $\left(\mathrm{PM}_{2.5}\right)$ and 
nitrogen dioxide $\left(\mathrm{NO}_{2}\right)$ in Chennai, India. Environ. Eng. Res. 2020;25(6):898-907.

13. Ielpo P, Mangia C, Marra GP, et al. Outdoor spatial distribution and indoor levels of $\mathrm{NO}_{2}$ and $\mathrm{SO}_{2}$ in a high environmental risk site of Southern Italy. Sci. Total Environ. 2019;648:787-797.

14. Ryerson TB. Effect of petrochemical industrial emissions of reactive alkenes and NOx on tropospheric ozone formation in Houston, Texas. J. Geophys. Res. 2003;108:4249.

15. Jobson BT, Berkowitz CM, Kuster WC, et al. Hydrocarbon source signatures in Houston, Texas: Influence of the petrochemical industry. J. Geophys. Res. 2004;109:1-26.

16. Motta O, Cuccineiello R, Femina RL, Pironti C, Proto A. Development of new radial passive sampling device for atmospheric $\mathrm{NO}_{\mathrm{x}}$ determination. Talanta 2018;190:199-203.

17. Bangroy J, Janta R, Kaewrat J, Rattikansukha C, Sichum S. Nitrogen dioxide concentration and health risk assessment at schools: Case study Tha sala district, Nakhon Si Thammarat province. IOP conf. Ser. Earth Environ. Sci. 2020;476: 012134.

18. Wichmann J, Lind T, Nilsson MA-M, Bellander T. $\mathrm{PM}_{2.5}$, soot, and $\mathrm{NO}_{2}$ indoor-outdoor relationships at homes, pre-school, and schools in Stockholm, Sweden. Atmos. Environ. 2010;44: 4536-4544.

19. Olufemi AO, Mji A, Mukhola M. Health risks of exposure to air pollutants among students in schools in the vicinities of coal mines. Energy Explor. Exploit. 2019;37(6):1638-1656.

20. Zheng XY, Ding H, Jiang LN, et al. Association between air pollutants and asthma emergency room visits and hospital admissions in time-series studies: A systematic review and Meta-analysis. PLOS ONE 2015;10(9):e0138146.

21. Gehring U, Wijga AH, Hoek G, et al. Exposure to air pollution and development of asthma and rhinoconjunctivitis throughout childhood and adolescence: a population-based birth cohort study. Lancet Respir. Med. 2015;3(12):933-942.

22. Song J, Liu Y, Lu M. et al. Short-term exposure to nitrogen dioxide pollution and the risk of eye and adnexa diseases in Xinxiang, China. Atmos. Environ. 2019;218:117001.

23. Novaes P, Saldiva PHN, Matsuda M, et al. The effects of chronic exposure to traffic derived air pollution on the ocular surface. Environ. Res. 2010;110:372-374.

24. Department of Industrial Works. Data of Industrial plants in Rayong province. [Internet] Department of Industrial Works, Ministry of Industry; 2019 [Cited 1 January 2019]. Available from: http://www2.diw.go.th/factory/tumbol.asp.

25. Bootdee S, Chalemrom P, Chantara S. Validation and field application of tailor-made nitrogen dioxide passive sampler. Int. J. Environ. Sci. Technol. 2012;9(3):519-526.

26. Dika H, Masawe E, Iddi S, Rumanyika R. Plasma haemoglobin concentration among pregnant and non-pregnant women in
Mwanza: are we using correct reference values to diagnose anaemia in pregnancy?. Pan Afr. Med. J. 2018;30:93:1-6.

27. United States-Environmental Protection Agency (US-EPA). Exposure factors handbook: 2011 Edition. [Internet] National center for environmental assessment, Office of Research and Development, Washington DC, EPA/600/R-090/052F; 2011 [Cited 15 January 2019]. Available from: http://www.epa.gov.

28. United States-Environmental Protection Agency (US-EPA). Exposure assessment tools by routes-Inhalation [Internet] National center for environmental assessment, Office of Research and Development, Washington DC [Cited 30 September 2021]. Available from: https://www.epa.gov/expobox/exposure-assessment-tools-routes-inhalation.

29. Garbero V, Montalto A, Lazovic N, Salizzoni P, Berrone S, Soulhac L. The impact of the urban air pollution on the human health: A case-study in Turin. Air Pollution Modeling and its Application XXI. In: NATO Science for Peace and Security Series C: Environmental Security (Ed.). Dordrecht, Netherland: Springer Press; 2011. p. 729-732.

30. Rivas I, Querol X, Wright J, Sunyer J. How to protect school children from the neurodevelopmental harms of air pollution by interventions in the school environment in the urban context. Environ. Int. 2018;121:199-206.

31. Chithra VS, Shiva Nagendra SM. Impact of outdoor meteorology on indoor $\mathrm{PM}_{10}, \mathrm{PM}_{2.5}$ and $\mathrm{PM}_{1}$ concentrations in a naturally ventilated classroom. Urban Clim. 2014;10:77-91.

32. Zhang Z, Wang, J, Lu W. Exposure to nitrogen dioxide and chronic obstructive pulmonary disease (COPD) in adults: systematic review and meta-analysis. Environ. Sci. Pollut. Res. Int. 2018;25(15):15133-15145.

33. Flores-Pajot MC, Ofner M, Do MT, Lavigne E, Villeneuve PJ. Childhood autism spectrum disorders and exposure to nitrogen dioxide, and particulate matter air pollution: A review and meta-analysis. Environ. Res. 2016;151:763-776.

34. Zhong JY, Lee YC, Hsieh CJ, Tseng CC, Yiin LM. Association between dry eye disease, air pollution, and weather change in Taiwan. Int. J. Environ. Res. Public Health 2018;15:2269.

35. Jarvis DL, Leaderer BP, Chinn S, Burney PG. Indoor nitrous acid and respiratory symptoms and lung function in adults. Thorax 2005;60:474-479.

36. Norbäck D, Lu C, Zhang Y, et al. Source of indoor particulate matter (PM) and outdoor air pollution in China in relation to asthma, wheeze, rhinitis and eczema among pre-school children: Synergistic effects between antibiotics use and $\mathrm{PM}_{10}$ and second-hand smoke. Environ. Int. 2019;125:252-260.

37. Khamyingkert L, Thepanondh S. Analysis of industrial source concentration to ambient air concentration using AERMOD dispersion model. EnvironmentAsia 2016;9(1):28-36. 